\title{
Land use changes on Hiiumaa Island (north-western Estonia) in the last fifty years
}

\author{
A. Kaasik, J. Raet, K. Sepp, A. Leito \& V. Kuusemets \\ Institute of Agricultural and Environmental Sciences, \\ Estonian University of Life Sciences, Estonia
}

\begin{abstract}
Significant social, economic and political changes of the last 50 years have altered Estonian rural landscapes. The paper analyses changes in land use intensity and landscape patterns in the two main agricultural regions (altogether $267 \mathrm{~km}^{2}$ ) of Hiiumaa, the second largest island of Estonia. The spatial analysis of land use patterns, which was based on decoded aerial photos (ortophoto maps) from 1956 and 1984, the digital Basic Map of Estonia from 1998, fieldworks in 2004/5 and performed in GIS software MapInfo, showed an overall decrease in agricultural land (esp. in account of natural and wooded grasslands) and gradual increase in forested land. The greatest change in land use pattern took place between 1956 and 1984. By 1984, the traditional and extremely diverse patchy mosaic landscape pattern of 1956 had become much more simplified and polarised as a result of collectivisation, land reclamation and wider use of industrial methods in agriculture. Since the beginning of the 1990s remarkable changes in agricultural land use intensity, a sharp decline by the end of the 1990s and a slight revival by $2004 / 5$, have not yet caused any significant changes in landscape patterns.
\end{abstract}

Keywords: rural landscapes, land use change, Hiiumaa.

\section{Introduction}

There are several studies about general land use change in Estonia during the $20^{\text {th }}$ century. Mander and Palang have brought out the main tendencies like a considerable increase in forests, decrease in agricultural lands and continuing 
decline in grasslands; and the main socio-economic factors that have led to the land use change [1, 2]. Some of the driving forces like land reforms (in 1919, 1940, 1947 and 1989), deportations and collectivization (in 1940s) and formation of the Soviet border zone along the coastline are specific for Estonia or for the former Soviet (the so-called post-Soviet) countries only, but other more general factors, related to improvement of agricultural practices, urbanisation etc., as well as their impacts are widely spread all over the world. Concentration of agriculture, marginalization, land amelioration, use of bigger machines etc., have reshaped rural landscapes in many countries and have brought about the loss of valuable semi-natural land use types (e.g. wooded and coastal meadows etc.) that have formed as a result of long-term traditional agricultural practices $[3,4,5]$.

Unlike previous Estonian studies (e.g. Palang et al [2], Koppa [6], Tomson [7]), the current land use analysis is focused on the last 50 years, specially on agricultural landscapes and is based on large-scale cartographical materials (1:10 000). The study area embraces two agricultural regions in Hiiumaa: Hellamaa $\left(200 \mathrm{~km}^{2}\right)$ in the north-eastern and Vanamõisa $\left(\sim 67 \mathrm{~km}^{2}\right)$ in the southern part of the island, fig. 1. In Hiiumaa the share of agricultural land has drastically decreased from more than $65 \%$ in 1939 to less than $25 \%$ in 1992 [8] and nowadays most of the agricultural land use in Hiiumaa is concentrated in these regions.

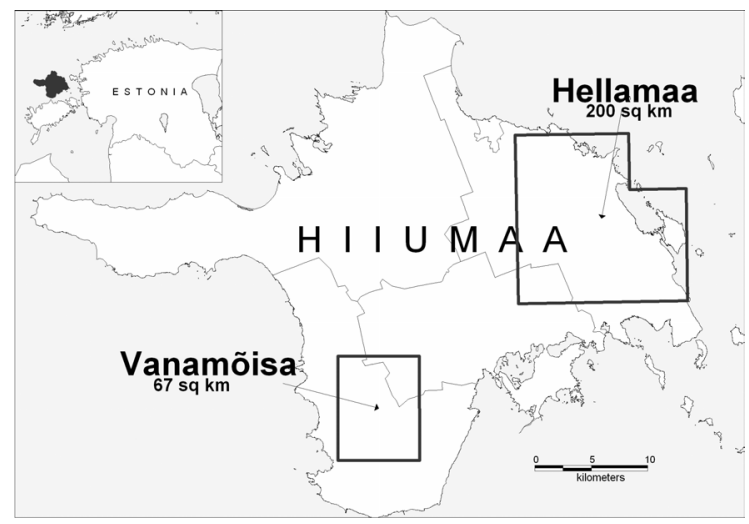

Figure 1: Location of study areas.

Due to relative isolation and poor preconditions for agriculture (young and mostly stony and thin soils on limestone), the landscape changes in Hiiumaa have been slower and the land use had retained more or less a traditional character by the middle of 1950s. So it was presumed that the first available aerial images from 1956 reflect the diverse land use pattern that had been developed by old traditional extensive agricultural practices during the first independence period (1918-1939) of Estonia. Different aspects of historical land use of Hiiumaa have been studied by many authors, e.g. Hellström has analysed the development of the farming landscapes, settlements etc. in the south-eastern part of the island since the middle of the $19^{\text {th }}$ century [9]. 


\section{Methology}

The landscape analysis was based on decoded aerial photos (ortophoto maps) from 1956 and 1984. The large-scale ortophoto maps (1: 10000$)$ were scanned and the land use patterns of 1956 and 1984 were digitized in GIS software MapInfo. The state of the present land use was identified by the digital Basic Map of Estonia (1:10 000) based on aerial images from 1998. In 1956, a slightly more detailed classification of land use was used and the additional land use types like pastures and fallowed fields were distinguished, but roughly the classification has remained quite similar. The main distinguished land use types were: fields, fallow fields (in 1956), grasslands, pastures (in 1956), bushes, sparse woodlands, young forests, forests, clearings and wind falls, mires, lakes, rivers and ditches, reed-beds, partly vegetated sandy and stony areas, ruderal areas, peat production areas, stone heaps, courtyards, buildings, roads, parks and greeneries, graveyards, quarries, power-line corridors and sea. In order to analyse the successive transformations between the land use categories, the land use types were digitized as precisely as possible, concerning grasslands, pastures and mires the existence of bushes, trees or both was defined. By field survey carried out in summer 2004/5, the actual land use, i.e. the fields still in use, long-term and short-term fallows, were identified. In many cases, the agricultural areas had been abandoned (not ploughed, moved or pastured) till the beginning of the 1990s (i.e. since the collapse of collective farming). The land use patterns were analysed and the first statistics and landscape metrics were calculated in MapInfo. In addition, large-scale (1: 10 000) land use maps of former collective and state farms, all compiled in 1983, were used.

\section{Findings}

The land use pattern of 1956 largely reflects the patchy mosaic landscape pattern of the previous independence period (1918-1939) which was characterised by comparatively small fields, grasslands and woodlots. By 1939 in Hiiumaa $71 \%$ of all land was owned or used by peasants, the average farm size was 23.4 ha [9] and the share of agricultural land (more than 65\%) was one of the highest in Estonia [8]. The landscape pattern of 1984 is much more simplified and polarised as a result of amelioration, collectivisation and a wider use of industrial methods in agriculture. By that time the former extremely diverse patchy type of landscape was re-organised and replaced by large fields and extensive forests, fig. 2.

The landscape patchiness has decreased steeply in both study areas from 1956 to 1984, fig 3(A). The total patchiness, with artificial objects (roads, buildings, etc.) excluded, follows the same tendency/trend from 15667 patches in 1956 to 8607 patches in 1984, fig. 3(B). The Edge Density (ED, m/ha) calculated for the terrestrial areas declined from 188.1 in 1956 to 137.7 in 1984. By 1998 the landscape pattern and patchiness (esp. concerning fields and cultivated grasslands and pastures) has remained almost the same as in 1984, only the majority of fields and grasslands were fallowed as the agricultural land use has attained probably the lowest level by that time. According to the Estonian Rural 


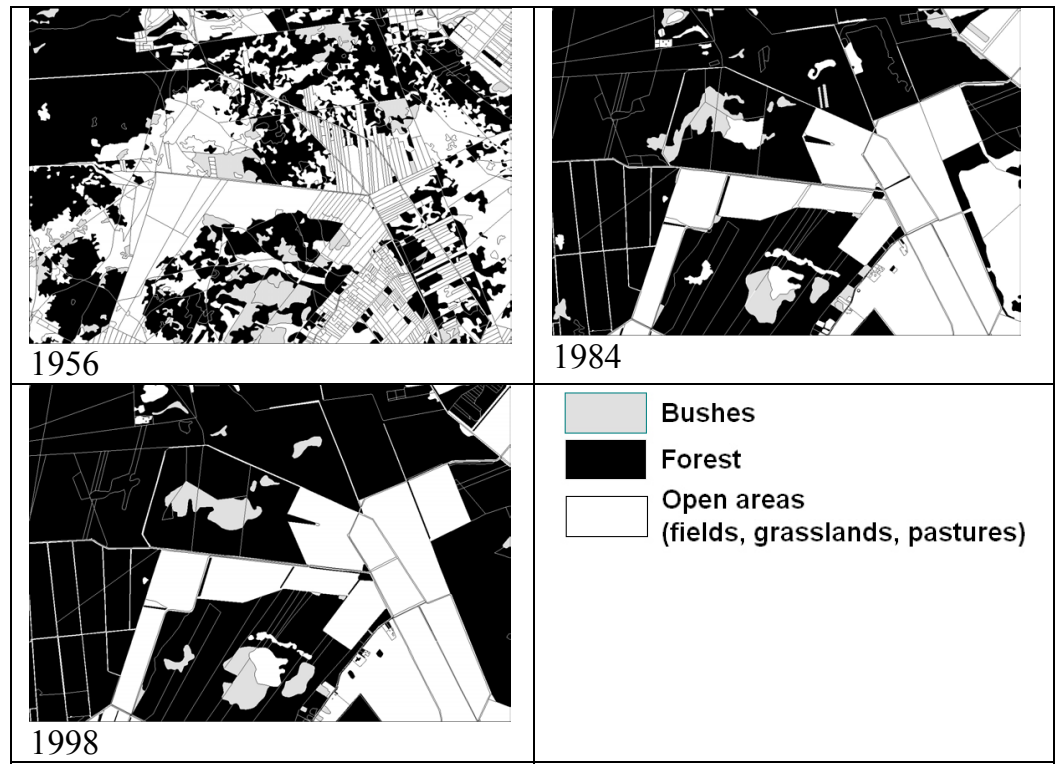

Figure 2: $\quad$ Examples of land use changes.
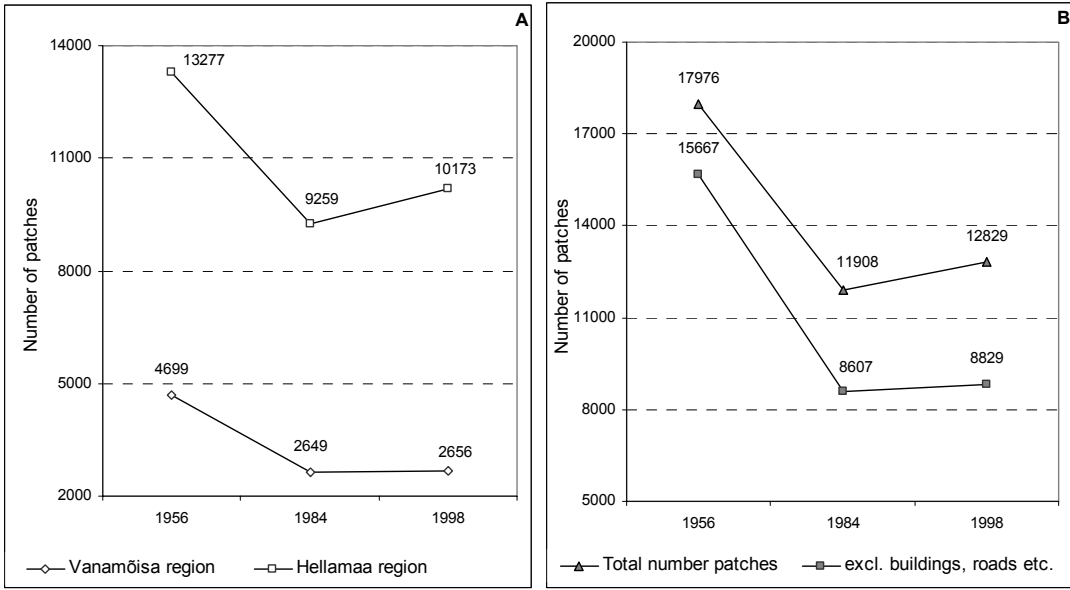

Figure 3: Change in landscape patchiness.

Development Plan of 2004-2006 (ERDP), the use of agricultural land in Hiiumaa has decreased by up to $50 \%$ from 1993 to 2001 [10].

Another tendency was the overall decrease in agricultural land (mainly in account of grasslands) and increase in forests, fig. 4. The land use changes were quite similar in both study areas, but in Hellamaa region the rise in forests was 


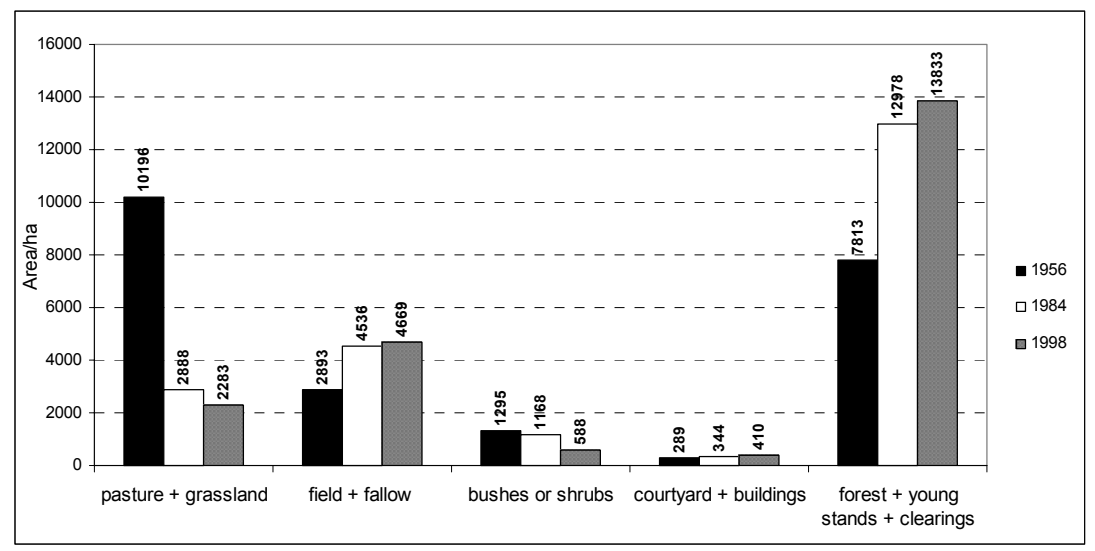

Figure 4: $\quad$ Changed land use.
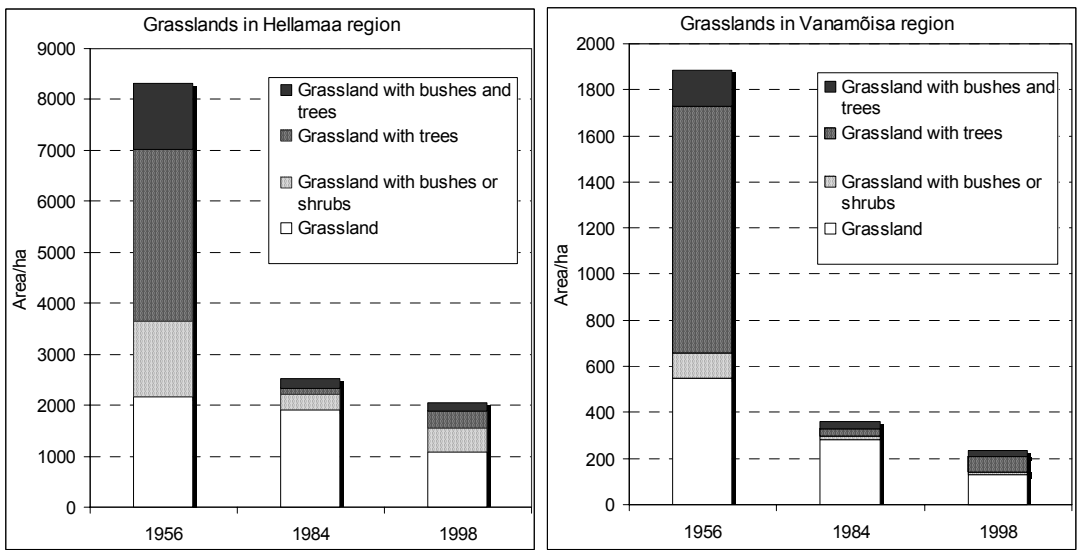

Figure 5: Decline in grasslands.

much more significant, the area of forests increased by more than twice during the observed period.

The share of grasslands and pastures has decreased significantly especially in account of natural and wooded meadows, i.e. grasslands with bushes and/or trees by our classification, fig 5 . Most of the grasslands have afforested or overgrown with shrubs while others have been turned into fields and cultivated grasslands or other land use categories. The total area of pastures in 1956 was 4505 ha. By 1984 more than half of the pastures $(50.4 \%)$ had transformed into forests and $13.4 \%$ into fields. The transformation of open grasslands (total area 5706 ha in 1956) was quite similar, by $198443.7 \%$ of the grasslands were transformed into forests and $24.4 \%$ into fields, fig. 6. From 1984 to 1998 , the transformation of previous pastures and grasslands continued mainly by successive 

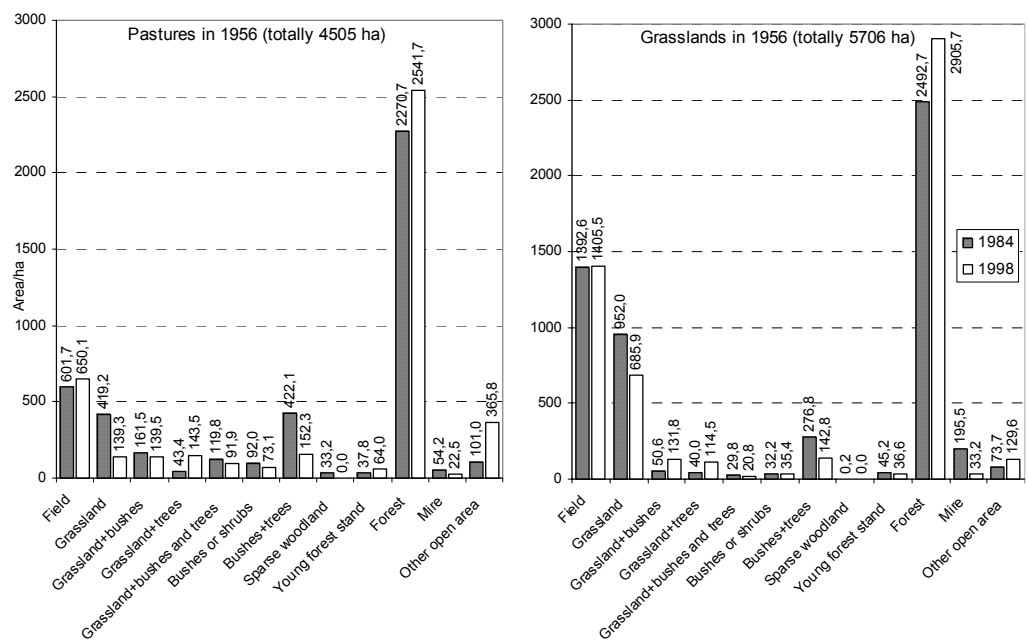

Figure 6: $\quad$ Transformation of pastures and grasslands from 1956 to 1998.

transformations, i.e. by gradual overgrowing with bushes and trees. By 1998 more than $56 \%$ of the pastures and about $51 \%$ of grasslands had transformed into forests and only $3.1 \%$ of the previous pastures and $12 \%$ of grasslands had maintained and were used as open grasslands.

The basic statistics about fields show a significant change between 1956 and 1984, when the total number of field patches had decreased in both regions (in Hellamaa region about 3 times and in Vanamõisa region 7 times, respectively). At the same time, the mean and maximum size of a field patch as well as the total area of fields had increased. Between 1984 and 1998, the above-mentioned tendencies leading to a homogeneity of fields' structure continued, but at a substantially slower rate. In 1998, the majority of fields that were included in calculations had been fallowed for a longer or shorter time, but were still classified as fields, fig. 7 . By that time, the agricultural land use had attained probably the lowest level [11]. The expectations that land re-privatisation and formation of small-scale private farms since the beginning of the 1990s would restore the diverse and wellmanaged rural scenery, that was characteristic of the previous independence period, did not come true by the end of the 1990s. In fact, a great portion of the privatised agricultural areas were fallowed by that time. According to ERDP, the use of agricultural land in Hiiumaa has decreased by up to 50\% from 1993 to 2001 [10]. In 2004, a slight revival in agricultural activity was observed, probably as a result of the enforcement of the EU agricultural subsidiary system. By that time some long-term fallowed fields and grasslands were freshly put into agricultural use again. A spatial analysis of the fields of 1956, 1998 and 2004 by soil fertility (expressed in soil quality points and identified on a large-scale digital Soil Map of Estonia) shows that the average soil fertility of the fields was quite uniform during the whole period: 35.4 in 1956, 37.7 in 1998 and 37.0 in 2004, respectively. 

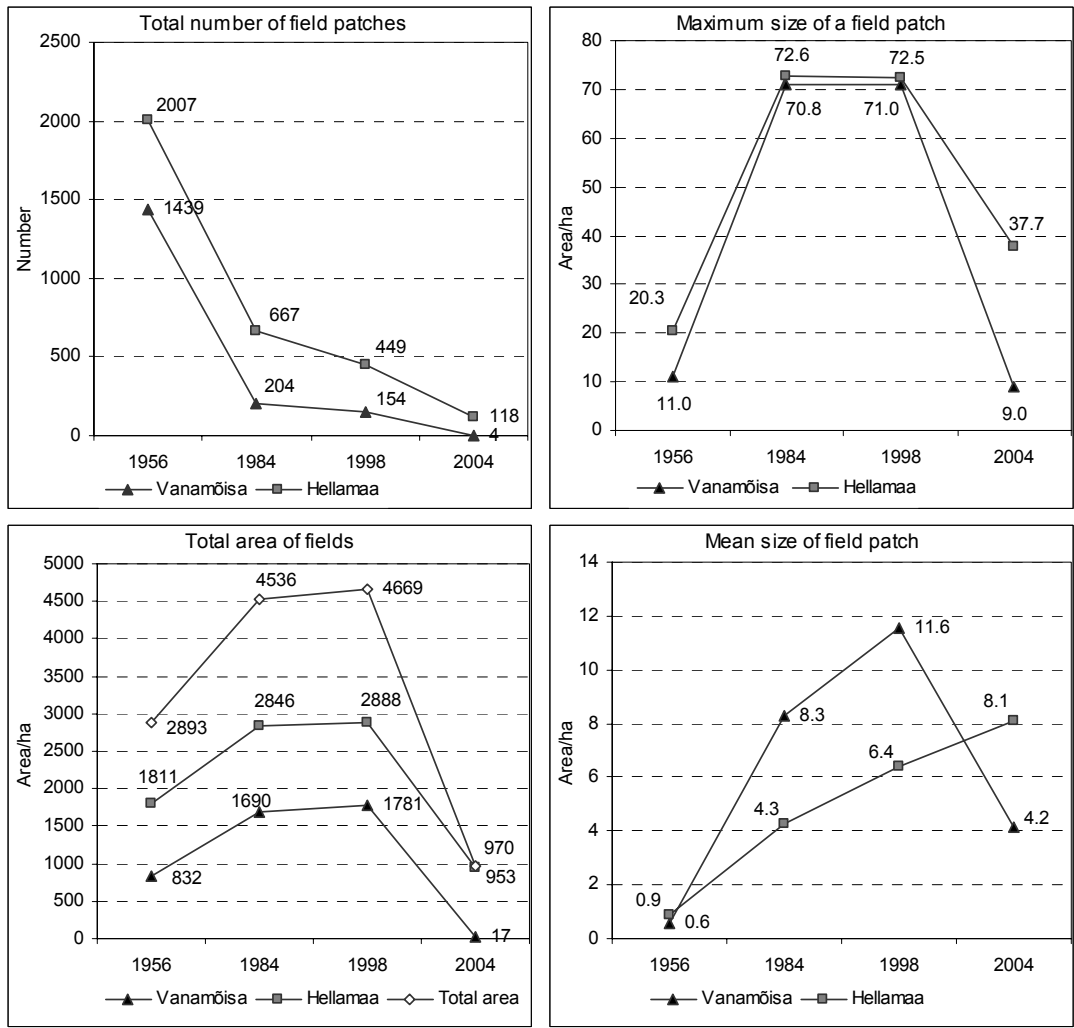

* 2004 - only cultivated field patches are taken into account

Figure 7: $\quad$ Some basic statistics about arable lands.

According to the land use maps of state and collective farms (compiled in 1983), in Hiiumaa the amelioration of agricultural lands was started in 1963 and was carried on till the beginning of the 1980s, although the major portion of reclamation works (altogether $92.3 \%$ of all reclaimed areas) were implemented between 1968 and 1979, fig. 8. Cyclic decrease and increase of lands embraced

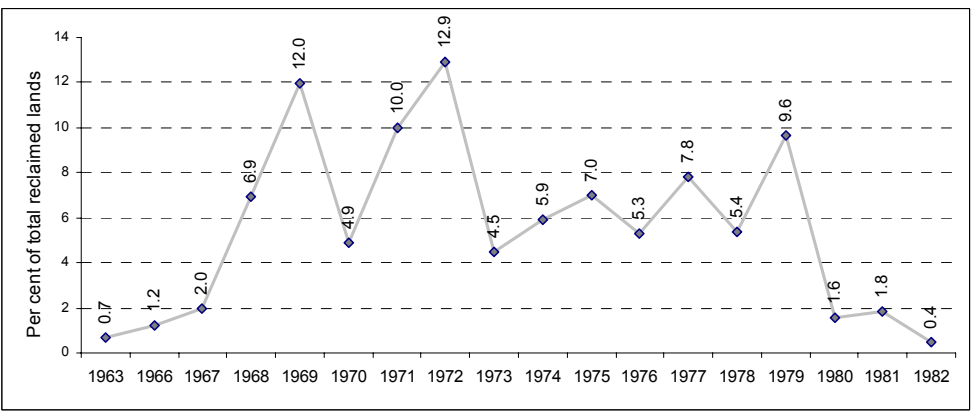

Figure 8: Amelioration of agricultural lands. 


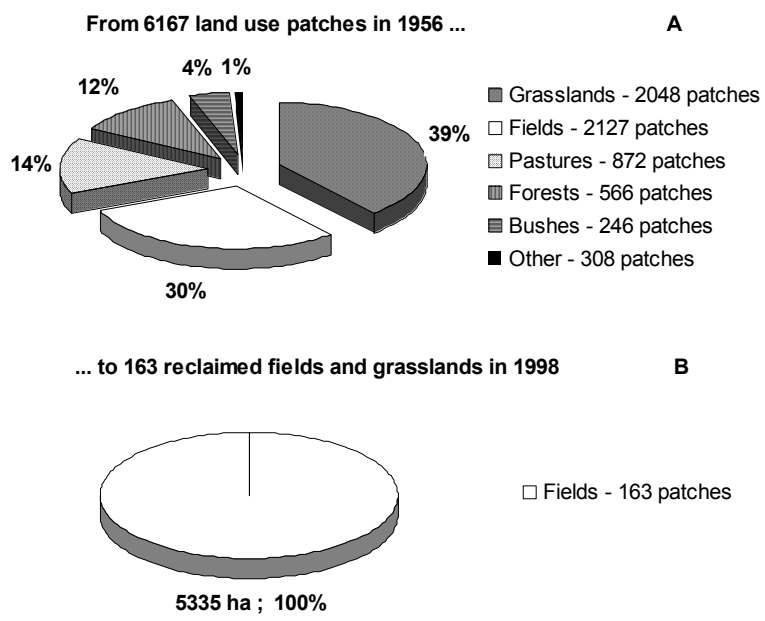

Figure 9: Simplification of landscape structure due to land reclamation.

to amelioration process can be related with state politics and five-year plans in its implementation.

In order to analyze the impact of land reclamation on the landscape structure, the larger ameliorated fields and cultivated grasslands (in total 163 fields) with a minimum size of 1.72 ha, maximum size of 236.3 ha, mean size of 32.7 ha and total area of 5335 ha were selected, fig 3(B). The spatial analysis inside the large ameliorated areas showed a significant simplification of land use structure. The 163 large fields that have formed as a result of land reclamation have transformed from 6167 tiny land use patches in 1956. The fields have been transformed mainly in account of grasslands and pastures (53\%, 2920 patches), former fields $(30 \%, 2127$ patches), forests $(12 \%, 566$ patches) and bushes $(4 \%)$, fig 3(A). Other land use types (roads, courtyards, mires and water bodies, etc.) formed altogether $1 \%$, whereby e.g. only 4 ha of mires (9 patches) and 7 ha of water bodies (lakes, ponds and streams; 26 patches) have disappeared due to land reclamation of the fields.

\section{Discussion}

The significantly changed land use and landscape pattern of Hiiumaa should influence the species composition, population numbers and distribution of species (incl. birds) living or staging in certain land use types. The main interest in the large-scale spatial land use data of the last 50 years was induced by an ambition to compare and combine it with the available biodiversity data, esp. with the existing reliable bird census data from the same period. Hiiumaa (but mainly its agricultural region) is an important place for many waterfowl and other species. Most impressive numbers of birds can be seen during the spring and autumn migration. For instance, the cranes and geese feed on their migration 
route practically only on agricultural land parcels (cereal fields, cultivated grasslands and pastures). It is supposed that their breeding success, as well as the species' general state and multitude are, to a high degree, dependent on these agricultural resources. For now, correlations between the numbers of the Eurasian Crane (Grus grus) and statistical data of cereal crops production has been already confirmed [12].

\section{Conclusions}

(1) In Hiiumaa the agricultural landscapes have changed considerably during the last 50 years.

(2) The land use pattern has simplified and polarised as a result of marginalisation, land reclamation, collectivisation and intensification of farming. The greatest decline in total patchiness and in edge density (ED) took place between 1956 and 1984.

(3) The area of agricultural lands has decreased in account of grasslands in total by about $43 \%$ and the area of forests has increased by about $44 \%$ from 1956 to 1998 . The share of grasslands has decreased significantly especially in account of natural types of grasslands.

(4) By 1998 more than half of the pastures and grasslands of 1956 were transformed into forests.

(5) Greatest decrease in field patchiness and increase in the total area of fields took place between 1956 and 1984. By 1998 the field patchiness and the area of fields had remained almost the same as in 1984, but actually the majority of fields were fallowed by that time. A slight revival in agricultural activity occurred in 2004, probably as a result of the enforcement of the EU agricultural subsidiary system. The remarkable changes in agricultural land use intensity since the beginning of the 1990s have not yet caused any considerable changes in landscape patterns. As regards soil fertility, there was no significant difference between the used and abandoned fields in 2004.

(6) The major portion of reclamation works were done between 1968 and 1979. The ameliorated fields have been transformed mainly in account of grasslands and pastures (53\%), former fields $(30 \%)$, forests $(12 \%)$ and bushes (4\%). The 163 larger fields in 1998 have been transformed from more than 6000 land use patches in 1956.

\section{References}

[1] Mander, Ü. \& Palang, H., Changes of landscape structure in Estonia during the Soviet period. GeoJurnal, 33(1), pp 45-54, 1994.

[2] Palang, H., Mander, Ü. \& Luud, A., Landscape diversity changes in Estonia. Landscape and Urban Planning, 41, pp. 163-169, 1998.

[3] Ihse, M., Swedish agricultural landscapes - patterns and changes during the last 50 years, studied by aerial photos. Landscape and Urban Planning, 31, pp. 21-37, 1995. 
[4] Luoto, M., Rekolainen, S., Aakkula, J. \& Pykälä, J., Loss of plant species richness and habitat connectivity in grasslands associated with agricultural change in Finland. Ambio, 32(7), pp. 447-452, 2003.

[5] Kasepalu, A., Mis Peremees Jätab, Selle Mets Võtab [That Which the Master Leaves, the Woods Will Take], Valgus: Tallinn, 1991.

[6] Koppa, H., Ajaloolised kaardid maakasutuse dünaamika uurimisallikana Vana-Kuuste mõisa näitel [Land cover changes as indicated by historical maps: the case study from Vana-Kuuste manor, Estonia], MSc thesis, Institute of Geography, University of Tartu: Tartu, 2006 [manuscript in Tartu University Library].

[7] Tomson, P., Ajaloolise Maakasutuse Mõju Karula Rahvuspargi Maastike, Koosluste ja Kaitsekorra Kujunemisele [The Impacts of Historical Land Use on Formation of Landscapes and Biotypes and Development of the Protection Regime in Karula National Park], MSc thesis, Institute of Agricultural and Environmental Sciences, Estonian University of Life Sciences: Tartu, 2007 [manuscript in Library of Estonian University of Life Sciences].

[8] Mander, Ü. \& Palang, H., Landscape changes in Estonia: reasons, processes, consequences. Land-Use Changes and Their Environmental Impact in Rural Areas in Europe. MAB Series, Vol. 24, eds. R. Krnert, J. Baudry, I.R. Bowler \& A. Reenberg, The Parthenon Publishing Group: Paris, pp. 165-187, 1999.

[9] Hellström, K., Agricultural Reforms and Policies Reflected in the Farming Landscapes of Hiiumaa from 1850 to 2000, PhD thesis, Swedish University of Agricultural Sciences: Alnarp, 2002.

[10] Estonian Rural Development Plan 2004-2006. Estonian Ministry of Agriculture, Tallinn, 2005. http:/www.agri.ee/public/juurkataloog/ TRÜKISED/s_raamat_eng_01.pdf

[11] Peterson, U. \& Aunap, R., Changes in agricultural land use in Estonia in the 1990s detected with multitemporal Landsat MSS imagery. Landscape and Urban Planning, 41, pp. 193-201, 1998.

[12] Leito, A., Truu, J., Õunsaar, M., Sepp, K., Kaasik, A., Ojaste, I. \& Mägi, E., The impact of agricultural policy and practice on birds: a case study of autumn staging Eurasian cranes in Estonia. Agricultural and Food Science, 17(1), 2008 [in press]. 